\title{
A Detailed Experimental Study on The Flexural Behaviour of Concrete Filled Steel Tube Beams
}

\author{
Shaik Heena ${ }^{1}$, Syed Rizwan ${ }^{2}$, A.B.S. Dadapeer ${ }^{3}$ \\ ${ }^{{ }_{1}}$ M.Tech, St.Mark Eucational Institution Society Group of Institutions, Anantapur, Andhra Pradesh, India \\ ${ }^{2,3}$ Assistant Professor, Civil Engineering Department, Chiranjeevi Reddy Institute of Engineering \& \\ Technology, Anantapur, Andhra Pradesh, India
}

\begin{abstract}
Concrete filled steel tubes (CFST) member have many advantages compared with the ordinary structural member made of steel or reinforced concrete. One of the main advantages is the interaction between the steel tube and concrete. Concrete delays the steel tube's local buckling, whereas the steel tube confines the concrete and thereby increases the concrete's strength. CFSTs are economical and permit rapid construction because the steel tube serves as formwork and reinforcement to the concrete fill, negating the need for either. The deformation capacity of the system is increased by the combined action of the concrete fill with the thin, ductile steel tube. The concrete fill significantly increases inelastic deformation capacity and the compressive stiffness and load capacity of the CFST member. In building construction concrete filled steel tubes are very widely used for columns in combination with steel or reinforced concrete beam. In this work totally 9 specimens were tested out of which 3 specimens were empty steel tubes and remaining 6 specimens were concrete filled with different bonding techniques. As it is prefabricated time consumption will be less in construction practice and due to confinement more ductility is expected which is very useful in earthquake resistant structures. Load carrying capacity of CFST almost doubled in comparison with empty steel tubes. Ultimate load carrying capacity of concrete filled steel tube beams almost doubled compared to empty steel tubes. Compared to empty steel tubes, strength increase of $67.19 \%, 97.48 \%$ and $114.84 \%$ was observed in normal CFST, CFST with sand blasting and CFST with diagonal shear connector beams respectively. Average ultimate load of EST was 105.66kN whereas average load of CFSTB, CFSTBWSB and CFSTBWDSC was 176.66, 208.66 and $227 \mathrm{kN}$ respectively. The maximum load was taken by the specimen CFSTBWDSC - 03 which was $231 \mathrm{kN}$, it may be because of presence of diagonal shear connector inside the tube.
\end{abstract}

Keywords : CFST, Fine aggregate, Compressive Strength, Formwork, Split Tensile Strength

\section{INTRODUCTION}

Building construction has been carried out from ancient times. Construction of building turned out to be a need due to the various climatic variations. Shelters were one means by which humans could adapt themselves to a variation in weather conditions. Earlier human shelters were very simple and it lasted just for few days or months. As time passed, they started building temporary structures which were evolved into refined forms as igloo. Gradually durability of structures began to improve, particularly after the beginning of agriculture, when people stayed in one place for longer duration of time. Structures slowly started having symbolic value and functional value, when people began to notice the difference between architecture and structural aspects. The history of buildings has been improving day by day. One is by increasing the durability of the materials used. Initially materials used in building 
were perishable, like leaves, branches, and animal skin. Later, materials which had additional durability like clay, stones, timber (wood), and other synthetic materials, like brick, concrete, metals, and plastics were used. Another evolution is the height and span of building which were constructed; this was made possible by the development of stronger materials and knowledge of how materials behave under situations and how to use them to greater advantage. The present state of building construction is very much complex.

\section{COMPOSITE CONSTRUCTION}

Composite construction, in the general sense, is the use of different materials or methods of construction within one structural element in a way that utilizes the properties of each to the best advantage. The term 'composite construction' has, within the construction industry, become accepted as meaning the position of structural steel and concrete with some shear connection between the two materials to enable composite action within the resulting structural member. Research into composite steel/concrete construction began in Canada in the 1920s.

\section{ADVANTAGES OF COMPOSITE CONSTRUCTION:}

1. The most effective use of steel and concrete is attained compositely.

2. Keeping the length and loading constant, economical steel section (with the aspect of depth and weight) is suitable in composite construction compared to the conventional construction.

3. As the depth of beam is reduced, the construction depth is also reduced, resulting in enhanced headroom.

4. Because has great stiffness, composite beams have less deflection compared to steel beams.

5. Composite construction is open to "fast-track" construction as rolled steel and pre-fabricated components are usually adopted.
Encased steel beam sections have good fire resistance and corrosion.

\section{Disadvantages of Composite Construction}

1. Installation of shear connector in another operation to be included in the schedule.

2. Slip of concrete occurs between steel concrete interface, care must be taken to avoid this.

3. The additional subcontractor needed for installation of shear connector increases the field costs.

\section{Types of Composite System for Buildings}

Composite Slabs: This is the recent introduction which has greater strength which can be achieved if profiled steel sheeting is considered in strength calculations. It also provides permanent and primary reinforcement; henceforth it is possible for elimination of wooden formwork.

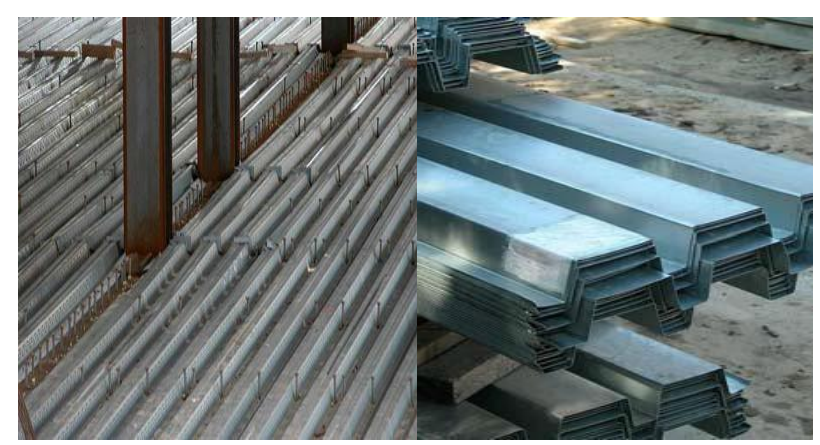

Figure 1 : Different forms of steel decking sheets

Composite Beams: Steel-concrete composite beams are the economical structural system in steel structures (multistoried) and bridges. By composite beam concept the steel and concrete becomes rigid and proves to be stronger than the sum of the individual members. Composite beams improve the properties of individual members due to the combined action. For example, in steel-composite concrete is good in compression and steel is good in tension. 


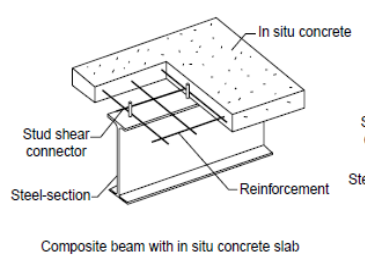

(a)

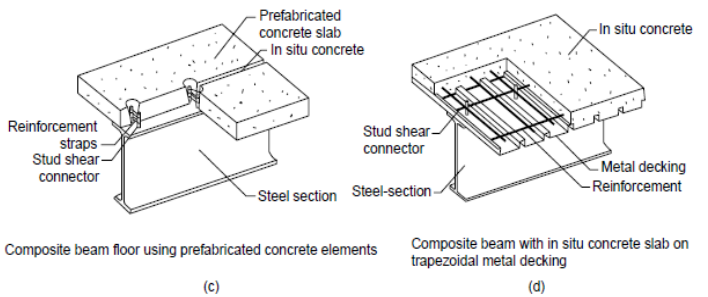

Figure 2 : Different forms of composite beam and slabs

Composite Column: Making columns composite, either as encased open sections or filled structural hollow sections, with or without reinforcement, not only increases the load-carrying capacity of the columns but also improves their fire resistance.

\section{CONCRETE FILLED STEEL TUBES (CFST)}

Concrete Filled Steel Tubes (CFSTs) are composite members consisting of steel tubes and concrete infilling in it, they work compositely to carry load and offer stiffness. Boundary stresses between these two materials are required to build up this composite action. Concrete-filled steel tubes have worldwide application including columns, platforms which support offshore structures, storage tank roofs, piers of bridges, and piles. Due to their good and stable engineering properties they are used in both seismic zones and non-seismic zones. Application of the Concrete Filled Steel Tube (CFST) concept can lead to largely savings of steel when compared to the conventional structural steel systems.

\section{FLEXURAL BEHAVIOUR OF CFST:}

- We first need to understand how the composite concrete filled steel tube members behave under flexural loading for its effective design.
- During the analysis of the flexural behaviour or flexural capacity of these concrete filled steel tube members, the concrete alters behaviour of the overall composite member in flexure and offers resistance to compression and also reduces the local buckling of steel in compression.

- Due to the filler concrete, there is increase in moment carrying capacity in the member and thereby there is increase in energy absorption capacity of the CSFT.

\section{APPLICATION OF CONCRETE FILLED STEEL TUBES:}

Concrete filled steel tube Columns (CFSTC): In modern constructions, concrete-filled steel tubular columns have gradually become a choice in structural systems like buildings, bridges etc. Concrete Filled Steel Tube Columns have been used world-wide due to their axial compression making it better than the conventional reinforced concrete and structural steel system in terms of its stiffness, strength aspects, its ductility, and energy absorption capacity. CSFT provides good axial load carrying capacity and also gives limiting pressure to the core of concrete as the core takes axial load and resists the local buckling of steel sections. Concrete Filled Steel Tubes also have an important advantage that during construction it doesn't need any form work and hence reduces the construction cost overall.

\section{EXPERIMENTAL WORK}

Brief procedure of experimental work carried out for this thesis work is explained in this part.

\section{SPECIMENS}

This experimental work was conducted to check the flexural behaviour of empty steel tube and concrete filled steel tube beams. Main objective was to find out the ultimate flexural strengths of empty and concrete 
filled steel tube beams. All specimens were of uniform cross section $120 \mathrm{mmx} 60 \mathrm{~mm}$ of thickness $3.2 \mathrm{~mm}$ and of length $1000 \mathrm{~mm}$. Steel tubes were confirming to Indian Standard code IS 4923 : 1997. All specimens were tested under two point loading with simple supports in Universal Testing Machine (UTM) of capacity 60 tonnes.

\section{CASTING OF SPECIMENS}

Empty steel tubes were available in 06 metre length. Each length was cut into 6 pieces of 1 metre length.

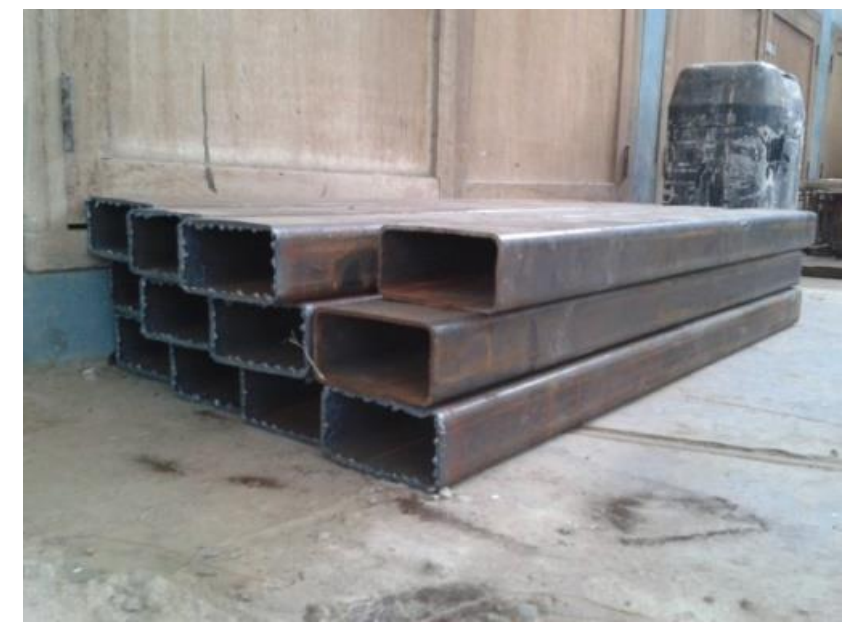

Figure 3 : Empty steel tubes

\section{SAND-BLASTING OF SPECIMENS}

For 3 numbers of specimens, inner surface of tubes were roughened to develop the bond between steel and concrete with epoxy resin araldite and manufactured sand (M-sand) particles of grain size retaining on $3.35 \mathrm{~mm}$ sieve.

First inner surface was cleaned for dust and corrosion particles then a layer of Araldite was applied on inner surface and then $\mathrm{M}$-sand particles were sprinkled on that surface. Then the steel tube was left for 24 hours undisturbed.

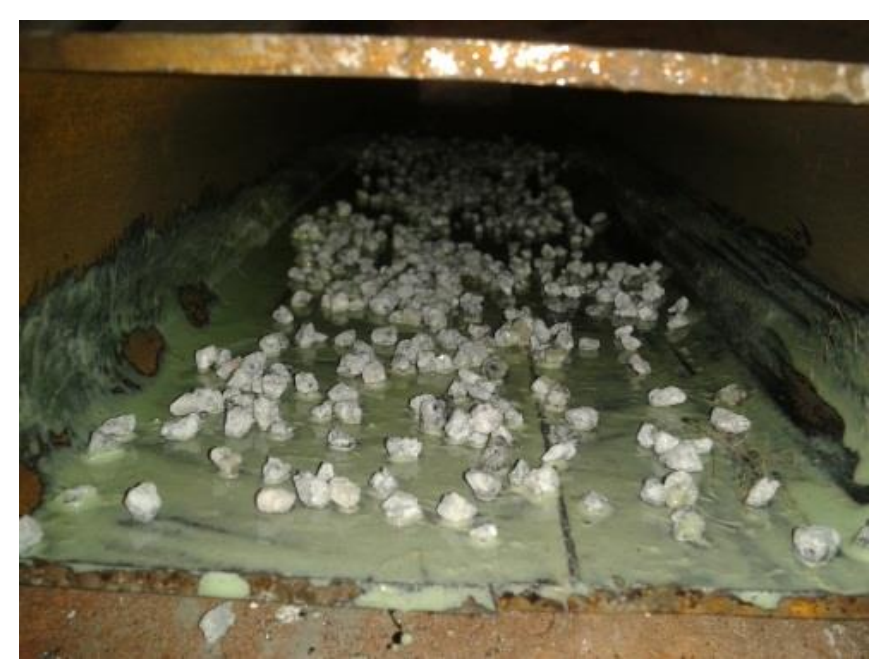

Figure 4 : Application of epoxy and M- sand particles

\section{CONCRETING OF SPECIMENS:}

Totally 9 specimens were filled with M25 grade of concrete. To ensure full compaction, TULASI concrete with collapsible slump was used. Concreting has been done at TULASI RMC plant.

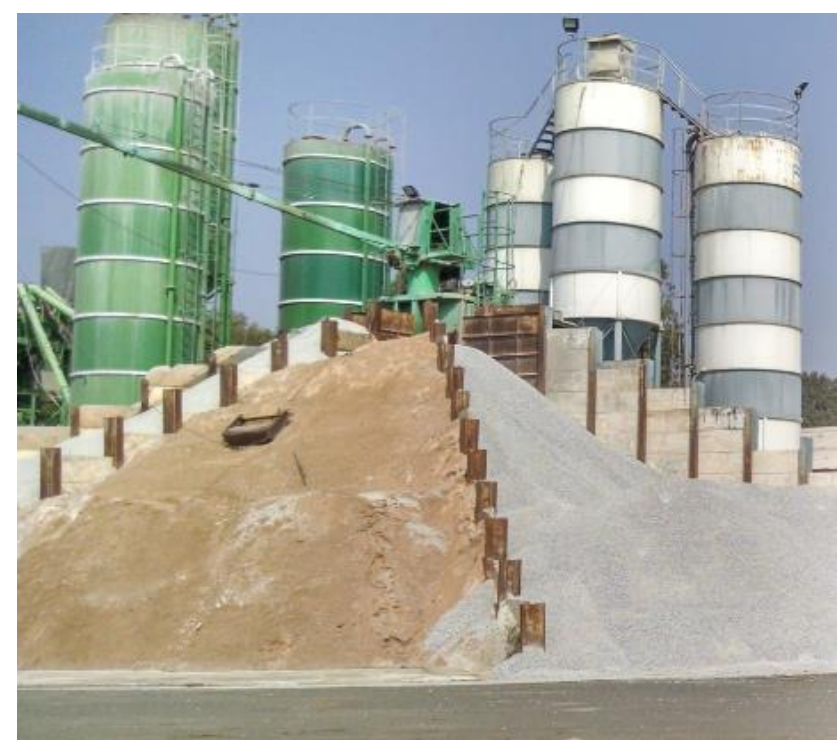

Figure 5 : RMC plant

\section{CURING OF SPECIMENS}

Concrete filled tubes were cured by immersing one end of the tube in water and constant application of water at the other end for 28days. 


\section{Test Setup}

All specimens were tested under two point static loading as simply supported condition with a span of $800 \mathrm{~mm}$. All specimens were tested in Universal Testing machine (UTM) of capacity 60tonnes.

Dial gauge was used to measure the deflection at mid span of the beam. The load was introduced at the rate of $2.5 \mathrm{kN} /$ minute. Deflections were noted down at every $2.5 \mathrm{kN}$ interval. Load was applied up to a point when the needle comes back and final load was noted down as ultimate load of the beam and at that load, final reading of dial gauge was noted down before releasing the load.

\section{THEORETICAL RESULTS}

Data: Yield Stress of tubes $=310 \mathrm{Mpa}$

Effective Span $=800 \mathrm{~mm}$

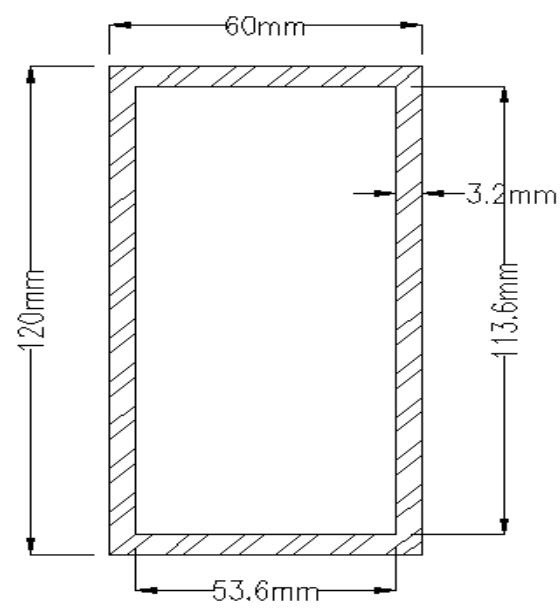

Figure 6 : Cross-Section of the TATA tube

\section{SECTIONAL MODULUS(Zy)}

$\mathrm{I}_{\mathrm{N} . \mathrm{A}}=\left\{\mathrm{BD}^{3} / 12\right\}-\left\{\mathrm{bd}^{3} / 12\right\}$

$\mathrm{I}_{\mathrm{N} . \mathrm{A}}=\left\{60 \mathrm{X} 120^{3} / 12\right\}-\left\{53.6 \mathrm{X} 113.6^{3} / 12\right\}$

$\mathrm{I}_{\mathrm{N} . \mathrm{A}}=2.0918 \mathrm{X} 10^{6} \mathrm{~mm}^{4}$

Sectional Modulus $\left(Z_{y}\right)=I_{N . A} / y$

$\mathrm{Z}_{\mathrm{y}}=2.0918 \mathrm{X} 10^{6} /(120 / 2)$

$Z_{y}=34.8643 \times 10^{3} \mathrm{~mm}^{3}$

\section{PLASTIC MODULUS (ZP)}

Plastic Modulus $\left(\mathrm{Z}_{\mathrm{p}}\right)=$ Summation $(\mathrm{A} X \mathrm{X})$

Plastic Modulus $\left(\mathrm{Z}_{\mathrm{p}}\right)=2 \mathrm{x}[(60 \mathrm{x} 3.2) \mathrm{x}(56.8+(3.2 / 2))$

$+\{2 \times(3.2 \times 56.8) \times(56.8 / 2)\}]$

Plastic Modulus $\left(\mathrm{Z}_{\mathrm{p}}\right)=43.075 \mathrm{X} 10^{3} \mathrm{~mm}^{3}$

\section{SHAPE FACTOR}

Shape Factor $(\mathrm{S})=$ Plastic Modulus $/$ Sectional

Modulus

Shape Factor $(\mathrm{S})=43.075 \times 10^{3} \mathrm{~mm}^{3 /} 34.8643 \times 10^{3}$

$\mathrm{mm}^{3}$

Shape Factor $(\mathrm{S})=1.2355$

\section{Moment Calculation}

Moment for 2point loading is $\mathrm{wL} / 3$

Therefore Moment $(M)=w L / 3$

Where $\mathrm{M}$ is the moment, $\mathrm{w}$ is the load in $\mathrm{kN}$ and $\mathrm{L}$ is the span of the specimen.

To determine the load, the equation is cross-

multiplied as below

Load $(w)=($ Moment x 3)/ Span

\section{Collapse Load}

Collapse load $(\mathrm{Wu})=($ Plastic Moment x 3)/ Span

Plastic Moment $\left(\mathrm{M}_{\mathrm{p}}\right)=$ Permissible yield stress $\mathrm{x}$

Plastic Modulus $\left(\mathrm{Z}_{\mathrm{P}}\right)$

Plastic Moment $\left(\mathrm{M}_{\mathrm{P}}\right)=310 \times 43.075$ X103 $=13.35325$

$\mathrm{X} 10^{6}$

Collapse load $(\mathrm{Wu})=13.35325$ X106/ 800

Collapse load $(\mathrm{Wu})=50.073 \mathrm{kN}$

\section{Service Load}

Service load $(\mathrm{Ww})=($ Elastic Moment x 3) $/$ Span

Elastic Moment $\left(\mathrm{M}_{\mathrm{e}}\right)=0.66 \times \mathrm{xPermissible}$ yield stress $\mathrm{x}$

Sectional Modulus $\left(\mathrm{Z}_{\mathrm{y}}\right)$

Elastic Moment $\left(\mathrm{Me}_{\mathrm{e}}\right)=0.66 \times 310 \times 34.843 \times 10^{3}$

$=6.48079 \times 10^{6}$

Service load $(\mathrm{Ww})=6.48079 \mathrm{X} 10^{6} / 800$

Service load $(\mathrm{Ww})=26.733 \mathrm{kN}$ 


\section{THEORETICAL DEFLECTION}

According to Moment Area and Conjugate Beam method of Determinate Beams, deflection of two point loading system is given by:

Deflection at mid span $=(23 / 648) \times\left(\mathrm{w} \mathrm{L}^{3} / \mathrm{EI}\right)$

Where

$\mathrm{w}=\operatorname{Load}(\mathrm{kN})$

$\mathrm{L}$ is the Span (mm)

$\mathrm{E}=$ Young's Modulus and

$\mathrm{I}=$ Moment of interia $\mathrm{mm}^{4}$

Deflection $=(23 / 648) \times\left\{\left(26.733 \times 10^{3} \times 800^{3}\right) /\left(2 \times 10^{5} \mathrm{x}\right.\right.$ 2.0918X106)

Deflection $=1.1611 \mathrm{~mm}$

\section{EXPERIMENTAL RESULTS}

All the specimens exhibited local buckling failure at compression zone and at concentrated load point. Ultimate load carrying capacity of concrete filled steel tube beams almost doubled compared to empty steel tubes.

Comparison of ultimate load vs. ultimate deflection of all specimens

To know the behaviour of each specimen, combined ultimate load vs. ultimate deflection is presented graphically for each type of specimen.

\section{EMPTY STEEL TUBES (EST)}

Failure pattern of all specimens in this set is same.

EST - 02 took maximum load.

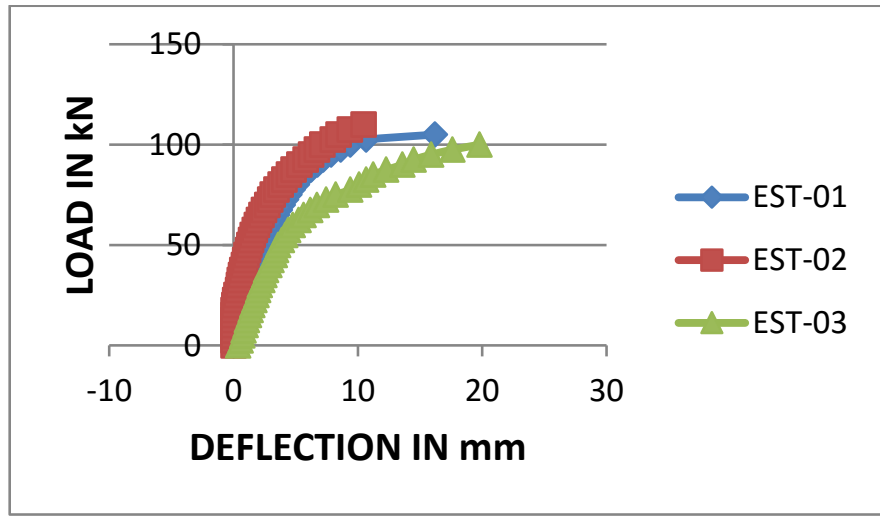

Figure 7 : Load vs. Deflection curve for EST - 01, 02, 03

\section{CONCRETE FILLED STEEL TUBES (CFSTB)}

Failure pattern of all specimens in this set is same. CFSTB - 03 took maximum load.

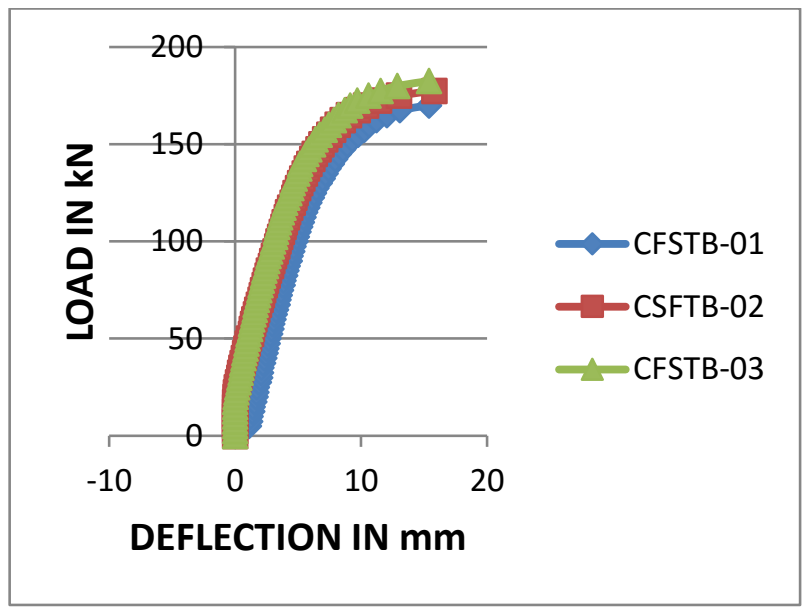

Figure 8 : Load vs. Deflection curve for CFSTB - 01, 02,03

\section{CONCRETE FILLED STEEL TUBES WITH SAND BLASTING (CFSTBWSB)}

Failure pattern of all specimens in this set is same. CFSTBWSB - 03 took maximum load.

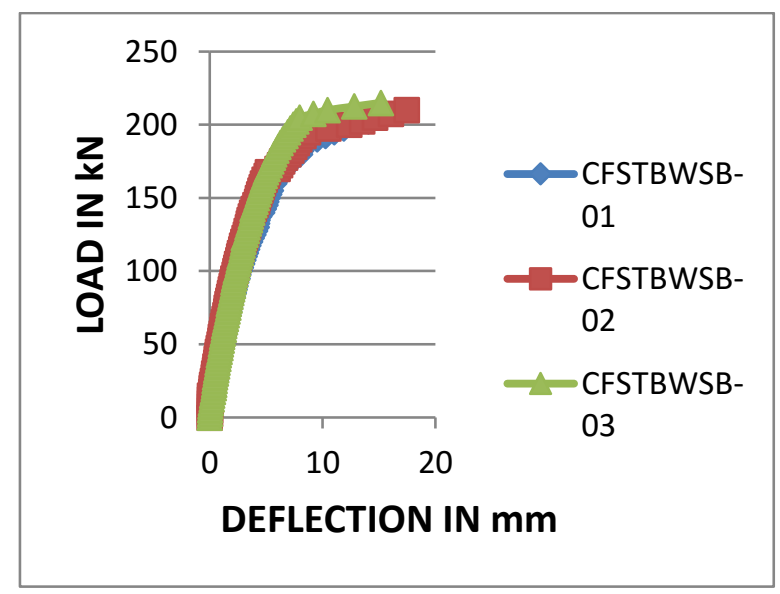

Figure 8 : Load vs. Deflection curve for CFSTBWSB 01, 02, 03

Concrete filled Steel Tube Beams with Diagonal Shear Connectors (CFSTBWDSC)

Failure pattern of all specimens in this set is same. CFSTBWDSC- 03 took maximum load. 


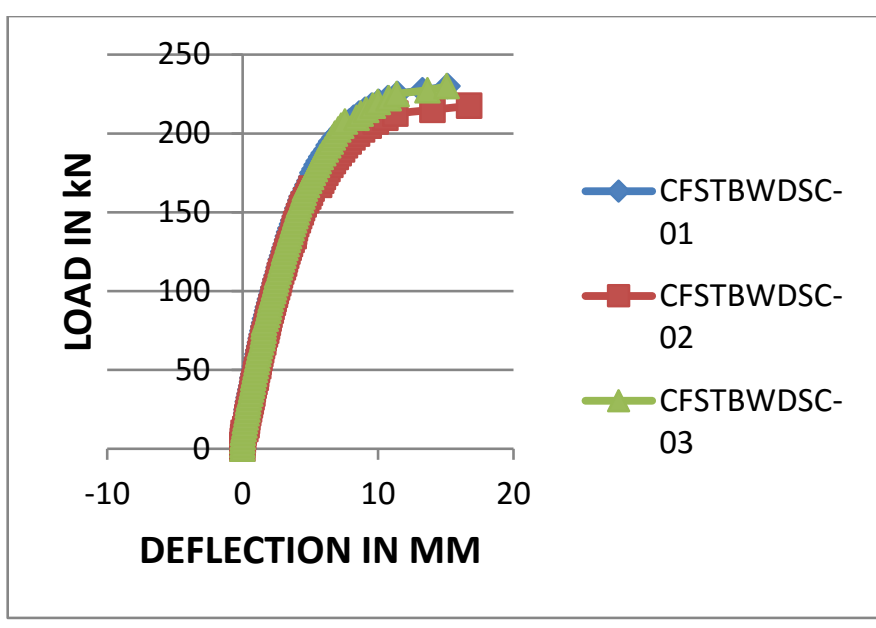

Figure 9 : Load vs. Deflection curve for CFSTBWDSC $-01,02,03$

\section{LOAD VS. DEFLECTION FORALL TYPE OF SPECIMENS}

To know the behaviour of all specimens together, a graph is plotted considering one specimen from each type. Considered specimen has achieved maximum load in that type. EST - 02, CFSTB - 03, CFSTBWSB - 03 and CFSTBWDSC - 03 achieved maximum load in each type respectively.

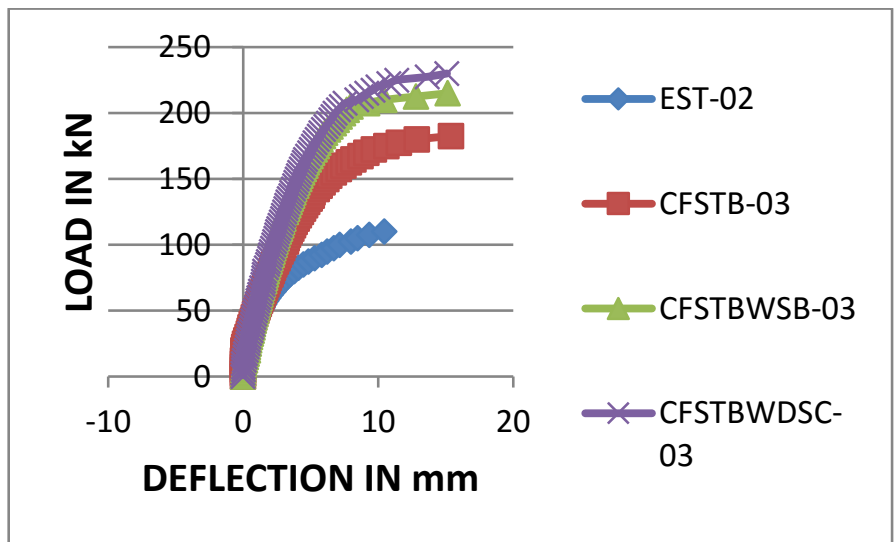

Figure 10 : Load vs. Deflection curve for each type of specimen

\section{CONCLUSIONS}

This study was conducted to know the flexural behaviour of empty steel tubes and concrete filled steel tubes with different bonding techniques. Totally 12 specimens were used. Cross section of steel tubes, thickness of steel tubes and grade of infill concrete used were kept constant so that the flexural behaviour of these tubes can be investigated thoroughly. An analytical model was also prepared using experimental results to know the comparison between experimental and analytical results keeping in mind that, further analytical results can be extended to full scale models. As concrete filled steel tubes are still not used as beams in structures, an attempt has been made to know the behaviour of these tubes to use as beams in construction industry.

From the experimental results, failure patterns, load deflection characteristics and analytical results, following conclusions have been drawn.

1. All the specimens failed almost in same pattern. Local buckling of steel tubes occurred at the compression zone and at point load.

2. Flexural load carrying capacity of concrete filled steel tubes doubled when compared to empty steel tubes.

3. Much difference between different bonding techniques was not seen in any of the specimen.

4. Almost all type of filled specimens failed at same load, but the maximum load was taken by the specimen CFSTBWDSC - 03, it may be because of presence of diagonal shear connector inside the tube.

5. There was no slip of concrete at the edges of beams observed in any specimen. This shows that the bond between steel and concrete is good enough.

6. The filled specimens are opened to check the behaviour, failure and crack pattern of in filled concrete. Very minute cracks were developed in flexure zone and crack spacing was also more.

7. It can be concluded that the smaller cross section of concrete filled steel tubes can carry much more load than normal reinforced concrete beams within the allowable crack width.

8. As concrete is confined by steel tube all around, sudden failure of beams may not occur. 
9. Overall performance of concrete filled steel tubes are good and can be concluded that filling of concrete to empty steel tubes increases the load carrying capacity to maximum extent.

\section{VII.SCOPE FOR FURTHER STUDIES}

1. Flexural behavior should be checked by changing the cross sectional dimension and thickness of the tubes.

2. Here static loading condition has been carried out, further it should be checked for dynamic loading condition also.

3. Full scale models should be analyzed to know the exact behavior of load and deflection.

4. Beam column connections with bolting and welding should be analyzed.

5. Behavior of these beams should be analyzed in conjunction with columns, preferably as concrete filled steel tube frames.

6. Fire and corrosion resistance analysis should be done with loads.

\section{REFERENCES}

[1]. Dr. Andrew Wheeler, Prof. Russell Bridge, "Flexure Behaviour of Conrete-Filled ThinWalled Steel Tubes with Longitudinal Reinforcement", School of Engineering; University of Western Sydney Locked Bag (2003), 99-130.

[2]. Arivalagan and Kandasamy, "Energy Absorption Capacity of Composite Beams, Journal of Engineering Science and Technology Review", 2 (1), (2009), 145-150.

[3]. Wie-Min Gho, Dalin Liu, "Flexural Behaviour of High-Strength Rectangular Concrete-Filled Steel Hollow Sections", Journal of Constructional Steel Research, 60, (2004), 1681-1696.

[4]. Jae-Yoon Kang, Eun-Suk Choi, Won-Jong Chin and Jung-Woo Lee, "Flexural Behavior of
Concrete-Filled Steel Tube Members and Its Application", Steel Structures, 7, (2007), 319324.

[5]. Aoyu Jiang, JuChen, Wei-liangJin, "Experimental Investigation And Design Of Thin Walled Concrete Filled Steel Tubes Subject To Bending", Thin-Walled Structures, 63,(2013), 44-50.

[6]. Jiho Moon, Charles W. Roeder, Dawn E. Lehman, Hak-Eun Lee, "Analytical Modeling of Bending of Circular Concrete-Filled Steel Tubes", Engineering Structures, 42, (2012), 349-361.

[7]. Xiao-Ling Zhao and Raphael Grzebieta, "VoidFilled SHS Beams Subjected To Large Deformation Cyclic Bending", Journal of Structural Engineering, September, (1999),125, 1020-1027.

[8]. M. Elchalakani, X.L. Zhao, R.H. Grzebieta, "Concrete-Filled Circular Steel Tubes Subjected To Pure Bending", Journal of Constructional Steel Research, 57, (2001),1141-1168. 